\title{
EFFECT OF ZINC AND EDTA AS ADDITIVES ON PRODUCTIVE PERFORMANCE AND CARCASS TRAITS OF BUFFALO MALE CALVES
}

\author{
Mahmoud, S. A.; Abou-seri, H.S. and Abdel-Latif A.F.I. \\ Buffalo Research Dep., Animal Production Research Institute, Agricultural Research Center, \\ Dokki, Giza, Egypt.
}

\section{SUMMARY}

Twenty male buffalo calves ranged between 8-12 months ofage with an average body weight $(194.5 \pm 6.85 \mathrm{~kg})$ were used to study the effect of adding Zn and EDTA as additives on growth performance and carcass characteristics. Animals were divided randomly into four groups $(n=5)$ according to their average weight, the $1^{\text {st }}$ group, $\left(T_{1}\right)$ fed on basal diet $+1 \mathrm{~g}$ zinc (Several zinc) /calf/day, the $2^{\text {nd }}\left(T_{2}\right)$ fed on basal diet which supplemented with $1 \mathrm{~g}$ EDTA /calf/day, the $3^{\text {rd }}\left(T_{3}\right)$ fed on basal diet $+1 \mathrm{~g}$ zinc $+1 \mathrm{~g}$ EDTA /calf/day, and the $4^{\text {th }}$ (C, control group) fed on basal diet only. Calves of $T_{1}$ and $T_{3}$ were gained more weight than $(C)$ by 15.8 and $4.0 \%$, respectively while $T_{2}$ gained less by $4.1 \%$ as compared with control. The average daily gain, feed intake and gain: feed ratio were not affected significantly by adding Zn or EDTA additives during the feeding trial. Dressing percentage (hot carcass weight basis), head, legs weight and edible meat weight did not differ among groups, while the weight oflunges, spleen and tests were differed significantly $(P<0.05)$. The highest value of edible meat content was detected of EDTA, zinc and EDTA+zinc groups by 27.15, 21.47, and $11.09 \%$, respectively compared with control group. Zinc group had attained the highest meat $(P<0.05)$ of high priced cuts than EDTA, EDTA+zinc and control groups. Results revealed that the differences among groups in best ribs components were insignificant. The carcasses of $\left(T_{1}\right)$ and $\left(T_{3}\right)$ groups recorded higher boneless meat percentage; $\left(T_{1}\right)$ group was higher for coefficient of meat ratio. The differences among treated groups in chemical composition and physical traits of $L$. dorsi muscle (9-10-1 $1^{\text {th }}$ rib) were significant in fat\%, ash\%, and $\mathrm{pH}$ value and non-significant for protein \%, tenderness, and waterholding capacity. Rib eye area was higher $(P<0.05)$ in calves fed zinc compared with the other groups. The increasing rib-eye areas in calves fed zinc may be explained by the greater carcass weights in the zinc treated group relative to the other groups.

\section{Keywords: Zn, EDTA, Buffalo, performance and carcass characteristics}

\section{INTRODUCTION}

Improving meat production from buffalo male calves are an important target to cover shortage in meat production in Egypt. The animal's performance depends on the influence of heredity and environmental factors. The main aim of better calves' management is to obtain optimum growth rate and to improve feed efficiency. Meat is produced in the form of gained in body weight by promoting the biological responses, to manipulate rumen fermentation by the dietary addition of a large variety of feed additives. Zinc ( $\mathrm{Zn}$ ) could hypothetically become an alternative growth promoter to ionophores when added in the diet at a higher concentration than the animal's requirement, and improved growth rate (Phiri et al., 2009), $\mathrm{Zn}$ deficiency in cattle causes parakeratosis, anorexia, growth failure, defective cell-mediated immunity and impaired reproductive function. Znic a component of numerous metal-enzymes and transcription factors (O’Dell, 2000), which plays significant roles in the metabolism of essential nutrients in ruminants (Jia et al., 2008). This metal is the second most abundant trace element in the body and it is not stored in the body, a continuous dietary intake is essential for body appropriate physiological functions (Zalewski et al., 2005). $\mathrm{Zn}$ could increase the concentration of rumen propionate and feed efficiency (Arelovich et al., 2000), and decrease the acetate: propionate ratio (Bateman et al., 2004). Ethylene diamine tetra acetic acid (EDTA) has been approved by the food and drug Administration as a food additives generally recognized safe. Additionally, EDTA is safety used as a chelating agent with heavy metals or mercury poisoning, a high dose of EDTA administered to someone in good health could have toxic effects, improve growth rate and mineral metabolism by EDTA havebeen shown by (Hakwins, 2014)

The aim of the present study is to investigate the effect of dietary zinc and EDTA as additives on animal performance and carcass characteristics measurements in male buffalo calves. 


\section{Materials and Methods}

This study was carried out at Mehalet Mosa Station, Animal Production Research Institute, Agriculture Research Center, Ministry of Agriculture, Egypt. The experimental period was extended for six months. Twenty buffalo male calves (Bubals bublus) with an age averaged between 8-12 months and have $194.5 \pm 6.85 \mathrm{~kg}$ initial live body weight (LBW) are divided into four random groups $(\mathrm{n}=5 / \mathrm{each})$ based on their initial weight and age. $T_{1}$ group was fed the basal diet $+1 \mathrm{~g}$ zinc (several zinc) /calf/day. Several zinc was produced by Egyptian United Company (EUC),Egypt. The ingredients of this compound are; 10 million IU/kg Vit A, 20 million IU/kg Vit D3, $10000 \mathrm{mg} / \mathrm{kg}$ Vit $\mathrm{A}$ and $50000 \mathrm{mg} / \mathrm{kg}$ zinc bacitracin. The ingredients in the product were carried by calcium carbonate up to $1 \mathrm{~kg} . \mathrm{T}_{2}$ group was fed the basal diet which supplemented with $1 \mathrm{~g}$ EDTA /calf/day, $\mathrm{T}_{3}$ group was fed the basal diet $+1 \mathrm{~g}$ zinc $+1 \mathrm{~g}$ EDTA/calve/day, the EDTA produced by ADWIC United Company (El-Nasr Pharmaceutical Chemical), Egypt. Control group animals (C) were fed the basaldiet without adding additives. Calves were housed in semi-open shad yards and feeding according to NRC allowances for fattening animals (NRC, 2000), The basal diet contain (concentrate mixture, berseem hay and rice straw), the concentrate feed mixture consists of $35.5 \%$ wheat bran, $31.5 \%$ undecorticated cotton seed cake, $15 \%$ yellow corn, $10 \%$ sun flower seed cake, $3.5 \%$ vinous, $3 \%$ limestone and $1.5 \%$ salt $(\mathrm{NaCl})$. Animals received the same feeding twice daily in the morning and afternoon in amounts adequate to allow ad-libitum access to feed after ad libitum watering system. Calves were weighed biweekly and average daily gain was calculated. At the end of experiment, three animals from each group were chosen randomly to be slaughtered after $16 \mathrm{hr}$ fasting period. After complete bleeding, animals were skinned and dressed out, weight of the following parts were recorded,

- Carcass offal's (liver, heart, lungs, kidneys, spleen and tests).

- Non carcass components (NCC) (head, hide, four legs, full and empty digestive tract).

- Residuals (RSC) (diaphragm, tail, gall bladder, and penis).

- Body fat (BF) (kidneys fat, heart-fat, and coal fat).

Each carcass was split into two halves, each half was divided between the $8^{\text {th }}$ and $9^{\text {th }}$ ribs into fore and hind-quarter, each quarter was weighed. Hot carcass weight (HCW) was recorded by the sum of four quarters. The two quarters of the left side of hot carcass were dis sected into bone and boneless meat and weighed.
- Dressing percentage was estimated as percentage of hot carcass weight.

High priced cuts weight calculated as described by Awadalla (1993). The percentages of carcass cuts were calculated as percentage of carcass weight. Longissimu dorsi at 9, 10, $11^{\text {th }}$ ribs cut weight was separated from the left side then dissected into lean, fat and bone, then weighed, meat included fat: bone ratio (coefficient of meat) was determined, eye muscle area was measured by plan-meter in square centimeters. Samples from $L$.dorsi muscle were used to determine meat physical characteristics as follow: $\mathrm{pH}$ value was measured $12 \mathrm{~h}$. after slaughtering by using Micro-computer $\mathrm{pH}$-vision model 6007 (Jenco)

- Water holding capacity (WHC) was determined according to Soloviev (1966) after $24 \mathrm{~h}$. chilling period at $4^{\circ} \mathrm{C}$,using Digital planimeterplanix 5.6.

Color intensity of meat-water extract and drip was determined according to the method described by Husaini et al. (1950).It was measured by using (Spectronic 21D absorbents at $542 \mathrm{~nm}$ weave length). $10 \mathrm{gm}$ of sample was shaken with $22.5 \mathrm{ml}$ distilled water in dark room for $10 \mathrm{~min}$., filtered and the color intensity was estimated.

- Two samples each of about $100 \mathrm{~g}$ from L.dorsiwere weighed to determined cooking loss and put in boiling water for 45 minutes from the time that the water boils again after that samples were removed from water and left to reach room temperature, and then reweighed to calculated the cooking loss as percentage from initial weight according to (El-Asheeri 1984).

- Chemical analysis was done also on L. dorsi samples at Sakha meat laboratory according to A.O.A.C (1990).

\section{Statistical Analysis}

Data were analyzed by a completely randomized One-way analys is of variance; all data are presented as least squares means. All calculations are completed using SAS (SAS Institute Inc., 1990). Duncan's multiple range tests (Duncan, 1955) is used for comparis on among means, considering $(P \leq 0.05)$ as a significant level.

$Y_{i j}=\mu+T_{i}+e_{i j}$

$Y_{i j}=$ Experimental observation

$\mu=$ The overall mean

$\mathrm{Ti}=$ Effect of treatment $(\mathrm{I}=1-4)$ where, $1=$ zinc Bacitracin, 2= EDTA, 3= zinc+EDTA and $4=$ control (no additives),

eij $=$ Experimental error assumed to be randomly distributed $(0, \sigma 2)$ 


\section{RESULTS AND DISCUSSION}

Results in Table (1) showed the effect of dietary Zn and EDTA supplementation on feed intake as DM intake $\mathrm{kg} /$ day/head (FI), average DM intake per $100 \mathrm{~kg}$ body weight, DM consumption per unit of metabolic body size (W0.75), average daily gain (ADG) and feeding efficiency. Results indicated that feed intake, ADG and feed efficiency increased with $\mathrm{Zn}$ supplementation (T1 \& T3 groups). However, the differences were insignificant among test groups. Mean daily DM intake ranged between 9.5 to 10.1 $\mathrm{kg} / \mathrm{head} /$ day. Corresponding figure for the consumption of DM as $\mathrm{kg} / 100 \mathrm{~kg}$ body weight was $5.2 \pm 0.09$ to $5.9 \pm 0.1$ and 181.97 to $193.7 \mathrm{gm} / \mathrm{w} 0.75$ which was in accordance with the expected feed intake of similar BW for calves. The average daily gain $(\mathrm{kg})$ for the animals fed EDTA ration $(0.89 \mathrm{~kg})$ was lower than those of animals fed zinc $(1.09 \mathrm{~kg})$ and for control group $(0.93 \mathrm{~kg})$ during the feeding period. Average relative growth rate was found in $\mathrm{T} 1$ and $\mathrm{T} 3$ groups was higher by 15.8 and $4.0 \%$, respectively, and lower by $4.1 \%$ in T2 compared with control group (C).

Feed efficiency improved by $\mathrm{Zn}$ inclusion may be attributed to high levels of $\mathrm{Zn}$ altered rumen fermentation to capture increased feed energy as VFA and decrease the acetate: propionate ratio (Bateman et al., 2002). In cattle, adding 250 to 400 $\mathrm{mg} \mathrm{Zn} / \mathrm{kg}-1 \mathrm{DM}$ of low-quality forage altered rumen fermentation by retarding ammonia

Table 1. Feed intake and efficiency (LSM+SE) of buffalo calves fed on zinc and EDTA as food additives

\begin{tabular}{|c|c|c|c|c|}
\hline Item & $\mathbf{C}$ & $\mathbf{T}_{1}$ & $\mathbf{T}_{2}$ & $\mathbf{T}_{\mathbf{3}}$ \\
\hline Initial weight(kg) & $194.6 \pm 7.4$ & $195.1 \pm 5.2$ & $194.9 \pm 8.55$ & $194.5 \pm 6.27$ \\
\hline Final weight $(\mathrm{kg})$ & $362.2 \pm 17.1$ & $391.3 \pm 14.6$ & $355.1 \pm 16.19$ & $369.2 \pm 18.01$ \\
\hline Daily gain $(\mathrm{kg})$ & $0.9 \pm 0.08$ & $1.089 \pm 0.10$ & $0.89 \pm 0.09$ & $0.97 \pm 0.07$ \\
\hline $\begin{array}{l}\text { Relative growth rate \% } \\
\text { ( basis on daily gain) } \\
\text { Average daily feed intake (FI) }\end{array}$ & $0.48 \pm 0.11$ & $0.558 \pm 0.09$ & $0.46 \pm 0.06$ & $0.49 \pm 0.07$ \\
\hline Daily DM intake $\mathrm{kg} /$ day/head & $9.6 \pm 0.48$ & $9.8 \pm 0.4$ & $9.5 \pm 0.38$ & $10.1 \pm 0.5$ \\
\hline $\mathrm{DM} \mathrm{kg} / 100 \mathrm{~kg} /$ day & $5.9 \pm 0.13$ & $5.6 \pm 0.06$ & $5.7 \pm 0.13$ & $5.16 \pm 0.08$ \\
\hline $\mathrm{DM} \mathrm{g/w^{0.75 } / \mathrm { day }}$ & $183.6 \pm 2.08$ & $188.4 \pm 2.6$ & $181.97 \pm 1.65$ & $193.65 \pm 3.01$ \\
\hline Feed conversion $(\mathrm{kg})$ & & & & \\
\hline $\begin{array}{l}\mathrm{Kg} \text { DM intake } / \mathrm{kg} \text { gain } \\
\text { Feed efficiency (FE) }\end{array}$ & $10.3 \pm 0.77$ & $9.03 \pm 0.59$ & $10.68 \pm 0.60$ & $10.4 \pm 0.7$ \\
\hline Kg gain / Kg DM intake & $0.09 \pm 0.00$ & $0.1 \pm 0.00$ & $0.09 \pm 0.00$ & $0.09 \pm 0.00$ \\
\hline
\end{tabular}

Results in Table (2) showed that hot carcas s weight was heavier in calves fed zinc compared with those fed EDTA, animals showed a tendency to gain more and consumed more feed. There was a slight increase in $\mathrm{T} 1$ and $\mathrm{T} 3$ groups by 1.04 to $1.01 \%$ compared with control group, although the differences among groups were insignificant. ElBasiony et al. (2001) observed similar DP\% ranged from 51.6 to 52.1 for buffalo males accumulation and increasing molar proportions of propionate (Arelovich et al., 2000). These results would be in agreement with those reported by (Spears and Kegley, 2002;Bateman et al., 2004 and Jia et al., 2008). Zinc improving antibiotic and body metabolism by reduce accumulation of high level of blood heavy metal atoms from an enzyme and formation of complexes of less toxic metals which are biologically less activation in liver, kidneys and therefore affects the water and feed intake (Szakva et al., 2009). On contrary to the present results, Malcolm-Callis et al., 2000; Salama et al., 2003; Mandal et al., 2007; Fadayifar et al., 2012 and Khalil et al., 2013 reported that they did'nt identify any effect of adding $300 \mathrm{ppm} \mathrm{Zn}$ on feed consumption, feed efficiency and ADG in weaning calves.

Adding EDTA with zinc for animals feed decreased the performance characteristics, this may be due to the interaction between EDTA and zinc and formation complex of metals which are biologically less active. Serge et al. (1992) reported that adding EDTA caused a significant depression in serum $\mathrm{Zn}$ availability with no significant effect on average daily gain, feed intake or efficiency of feed utilization in veal.

Results in Table (2) showed that the empty body weight was higher $(\mathrm{P}<0.05)$ in $\mathrm{T} 1(354.3 \mathrm{~kg})$ compared to $\mathrm{T} 3, \mathrm{~T} 2$ and $\mathrm{C}$ groups $(335.7,321.8$ and $325.7 \mathrm{~kg}$ ), respectively. Also full digestive tract weight was significantly higher $(\mathrm{P}<0.05)$ for $\mathrm{T} 1$ than $\mathrm{C}$ groups than $\mathrm{T} 2, \mathrm{~T} 3$ and $\mathrm{C}$ groups. 
trend. Also, the highest meat: bone ratio in buffalo carcass were found inT1 group (4.00). Meat coefficient was lower than that obtained El-
Basiony et al. (2001) for buffalo males, while slaughter weight was not affected by adding EDTA in veal (Serge et al., 1992).

Table 2.Carcas $S$ characteris tics and dressing percentage (LSM + SE) of buffalo calves fed on zinc and EDTA as food additives

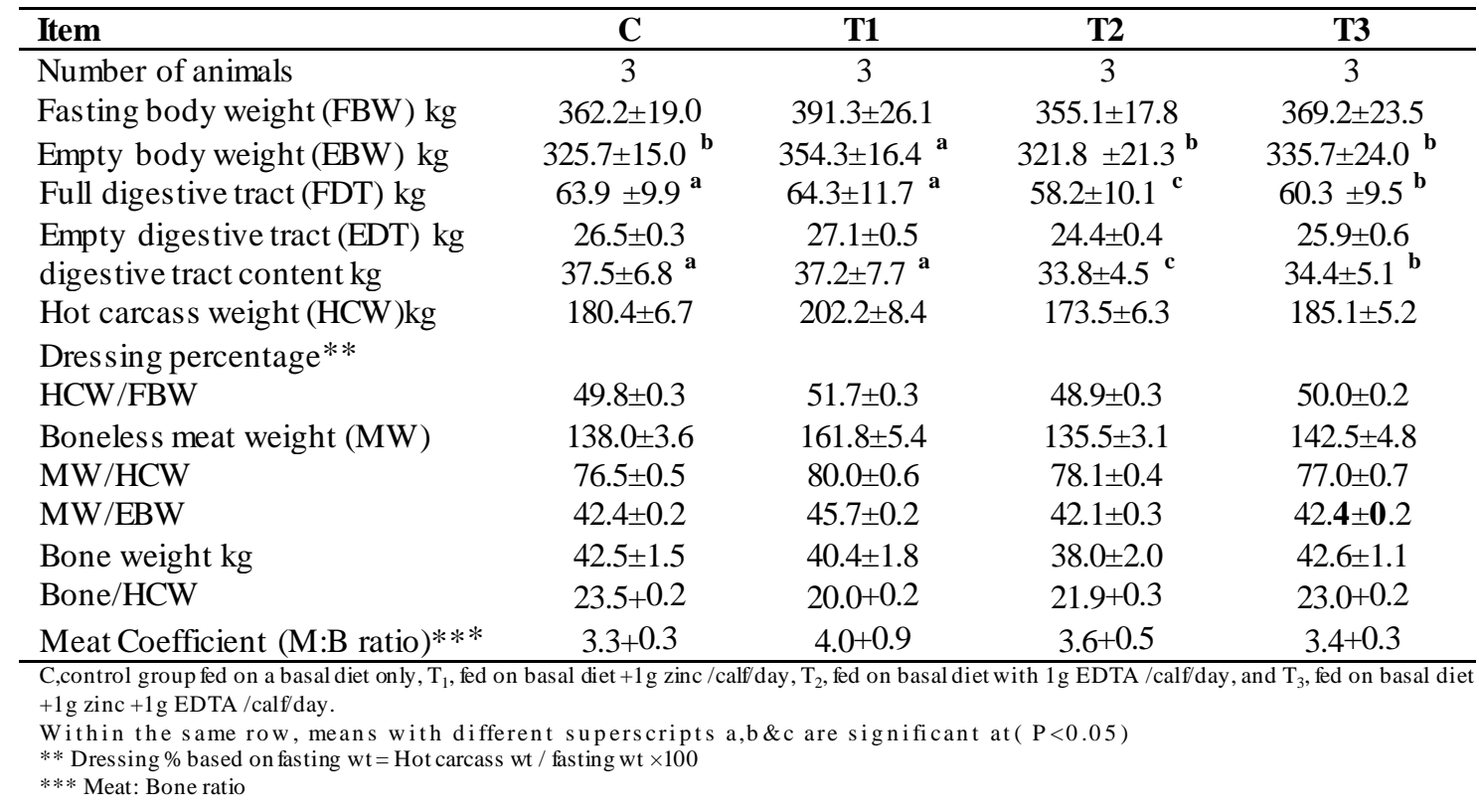

Table 3.Edible meat, offals and non-carcass components (LSM+SE) of buffalo calves fed on zinc and EDTA as food additives.

\begin{tabular}{|c|c|c|c|c|}
\hline Item & Control & T1 & $\mathbf{T 2}$ & T3 \\
\hline \multicolumn{5}{|l|}{ Offal's weights (kg) } \\
\hline Liver & $3.37 \pm 0.1$ & $4.66 \pm 0.3$ & $5 \pm 0.2$ & $4.35 \pm 0.1$ \\
\hline Heart & $1.27 \pm 0.0$ & $1.77 \pm 0.0$ & $1.84 \pm 0.0$ & $1.2 \pm 0.0$ \\
\hline Kidneys & $1.1 \pm 0.0$ & $1.33 \pm 0.0$ & $1.4 \pm 0.0$ & $1.3 \pm 0.0$ \\
\hline Lunges + trachea & $4.53 \pm 0.0^{\mathbf{b}}$ & $4.7 \pm 0.0^{\mathrm{a}}$ & $4.83 \pm 0.0{ }^{\mathrm{a}}$ & $4.5 \pm 0.0 \mathrm{~b}$ \\
\hline Spleen & $0.75 \pm 0.01^{\mathrm{c}}$ & $0.83 \pm 0.01^{\mathbf{b}}$ & $0.97 \pm 0.02^{\mathrm{a}}$ & $0.90 \pm 0.02^{\mathrm{a}}$ \\
\hline Testes & $0.25 \pm 0.0^{\mathbf{b}}$ & $0.4 \pm 0.0^{\mathrm{a}}$ & $0.29 \pm 0.0^{\mathbf{b}}$ & $0.27 \pm 0.0^{\mathbf{b}}$ \\
\hline Total offal's weight & $11.27 \pm 0.2$ & $13.69 \pm 0.4$ & $14.3 \overline{3} \pm 0.3$ & $12.52 \pm 0.1$ \\
\hline \multicolumn{5}{|c|}{ Non Carcass Components (NCC) } \\
\hline Head weight & $21.15 \pm 1.6$ & $22.5 \pm 1.8$ & $21 \pm 2.1$ & $21.77 \pm 1.2$ \\
\hline Hide weight & $36 \pm 0.1^{\mathbf{b}}$ & $37.90 \pm 0.3^{\mathrm{a}}$ & $36.43 \pm 0.2$ b & $36.12 \pm 0.2$ b \\
\hline 4 legs weight & $12 \pm 1.3$ & $12.6 \pm 1.7$ & $11.5 \pm 1.4$ & $11.9 \pm 2.0$ \\
\hline Gall bladder weight & $0.39 \pm 0.0$ & $0.37 \pm 0.0$ & $0.34 \pm 0.0$ & $0.41 \pm 0.0$ \\
\hline Tail weight & $1.64 \pm 0.0$ & $1.7 \pm 0.0$ & $1.48 \pm 0.0$ & $1.91 \pm 0.0$ \\
\hline Total NCC weight & $71.18 \pm 3.2$ & $75.07 \pm 3.9$ & $70.75 \pm 4.0$ & $72.11 \pm 3.5$ \\
\hline
\end{tabular}

The average weights of different carcass components are shown in Table (3). Offals weight was almost similar in all groups except the average weight of liver and heart which was heavier for $\mathrm{T}_{2}$ group $(5 \& 1.8 \mathrm{~kg}$, respectively).The differences in lunges, spleen and tests weights among groups were significant $(\mathrm{P}<0.05)$. The total edible meat weight was higher for $\mathrm{T}_{2}, \mathrm{~T}_{1}$ and $\mathrm{T}_{3}$ groups by $27.15,21.47$ and $11.9 \%$, respectively compared with $\mathrm{C}$ group. Non-carcas s components weight (e.g. head, legs, hide and tails) didn't show a remarkable difference among treated groups. Gregory (2006) indicated that carcass measurements not affected by feeding steers on $90 \mathrm{ppm}$ of zinc supplementation. Hierset al. (1967) showed that no consistent treatment effects on relative size of hearts, kidneys, or spleen of the animals when fed on $300 \mathrm{ppm}$ of EDTA. On the other hand, Malcolm-Callis et al. (2000) observed high percentage of kidney, pelvic and heart fat by feeding steers on $30 \mathrm{ppm}$ zinc supplement.

Concerning the high priced cuts (Table 4), significant differences $(\mathrm{P}<0.05)$ were observed among tested groups in round and high priced cut weight (HPCW), the highest weight was 
detected in $\mathrm{T}_{1}$ group $(89.21 \mathrm{~kg})$ compared with $\mathrm{T}_{3}$, $\mathrm{T}_{2}$ and $\mathrm{C}$ groups $(79.91,75.94$ and $73.95 \mathrm{~kg}$, respectively), also $T_{1}$ group tented to be higher HPCW percentage (on HCW basis) (44.11\%) compared with the other groups and similar for $\mathrm{T}_{2}, \mathrm{~T}_{3}$ and $\mathrm{C}$ groups. The present results were lower than what obtained by Awadalla (1993) for buffalo calves.

The results of best ribs physical components were presented in Table (5).C group had the lowest lean\% (65.0), while the 3 tested groups $\left(\mathrm{T}_{1}\right.$, $\mathrm{T}_{2}$ and $\mathrm{T}_{3}$ ) were similar in lean percentage (68.25,
68.96 and $69.49 \%$, respectively).The differences in fat $\%$ among tested groups were insignificant. The control group scored the highest percentage of fat $(13.3 \%)$, while $\mathrm{T}_{1}$ had the lowest value $(11.1 \%)$. Meat coefficient of best ribs (9-10 and $11^{\text {th }}$ ) in $\mathrm{T}_{3}$ and $\mathrm{T}_{2}$ groups was higher (3.73 and 3.48) compared with $T_{1}$ and control groups (3.31 and 3.00) respectively). The results were in agreement with the results reported by Omar (1997) and El-Kholy et al. (1999) using buffalo calves aged 18 months.

Table 4.The average weight and percentage of high priced cuts (HPC) (LSM + SE)of buffalo calves fed on zinc and EDTA as food additives.

\begin{tabular}{|c|c|c|c|c|}
\hline Item & $\mathrm{C}$ & $\mathbf{T}_{1}$ & $\mathbf{T}_{2}$ & $\mathbf{T}_{3}$ \\
\hline $\begin{array}{l}\text { Hot carcass weight } \\
(\mathrm{HCW}) \mathrm{kg}\end{array}$ & $180.4 \pm 6.7$ & $202.2 \pm 8.5$ & $173.5 \pm 6.4$ & $185.1 \pm 5.2$ \\
\hline Sirloin $(\mathrm{kg})$ & $10.5 \pm 0.39$ & $11.7 \pm 0.5$ & $10.0_{ \pm} 0.4$ & $10.7 \pm 0.3$ \\
\hline inside round $(\mathrm{kg})$ & $12.97^{\mathrm{b}} \pm 0.5$ & $16.5^{\bar{a}} \pm 0.6$ & $12.5^{\overline{\mathrm{b}}} \pm 0.5$ & $13.3^{\bar{b}} \pm 0.4$ \\
\hline Topside (kg) & $16.8^{\mathrm{b}} \pm 0.6$ & $19.9^{\mathrm{a}} \pm 0.8$ & $16.2^{\mathrm{b}} \pm 0.6$ & $17.3^{\mathrm{b}} \pm 0.5$ \\
\hline $\begin{array}{l}\text { eye of round } \\
+ \text { silverside }(\mathrm{kg})\end{array}$ & $18.7 \pm 0.7$ & $22.1 \pm 0.9$ & $18.9 \pm 0.7$ & $21.3 \pm 0.6$ \\
\hline prime rib $(\mathrm{kg})$ & $7.1_{ \pm 0.1}$ & $7.9 \pm 0.2$ & $6.8 \pm 0.1$ & $7.3 \pm 0.1$ \\
\hline Short loin $(\mathrm{kg})$ & $6.03 \pm 0.3$ & $6.8 \pm 0.3$ & $5.8 \pm 0.3$ & $6.2 \pm 0.2$ \\
\hline Tenderloin $(\mathrm{kg})$ & $3.9 \pm 0.2$ & $4.3 \pm 0.3$ & $3 . \overline{ \pm} 0.2$ & $3.9 \pm 0.2$ \\
\hline Total HPCW $(\mathrm{kg})^{* *}$ & $75.9^{\bar{c}} \pm 2.9$ & $89.2^{\bar{a}} \pm 3.6$ & $73.9^{\mathrm{c}} \pm 2.7$ & $79.9^{\bar{b}} \pm 2.2$ \\
\hline $\mathrm{HPCW} / \mathrm{HCW} \%$ & $42 . \overline{1}$ & 44.1 & $42 . \overline{6}$ & $43 . \overline{2}$ \\
\hline
\end{tabular}

Table 5. Average weight and percentage of best ribs $\left(9-10\right.$ and $\left.11^{\text {th }}\right)$ physical components $(\mathrm{LSM} \pm \mathbf{S E})$ of buffalo calves fed on zinc and EDTA as food additives.

\begin{tabular}{|c|c|c|c|c|}
\hline Item & $\mathbf{C}$ & $\mathbf{T}_{1}$ & $\mathbf{T}_{2}$ & $\mathbf{T}_{\mathbf{3}}$ \\
\hline \multicolumn{5}{|l|}{ Best ribs $\left(9-10-11^{\text {th }}\right)$ weight } \\
\hline Weight of best ribs $(\mathrm{kg})$ & $6.0 \pm 0.23$ & $6.3 \pm 0.24$ & $5.8 \pm 0.237$ & $5.9 \pm 0.193$ \\
\hline Lean weight $(\mathrm{kg})$ & $3.9 \pm 0.2$ & $4.3 \pm 0.1$ & $4 \pm 0.2$ & $4.1 \pm 0.1$ \\
\hline Lean $(\%)$ & $65.0 \pm 1.2$ & $68.25 \pm 0.8$ & $68.96 \pm 1.0$ & $69.49 \pm 0.7$ \\
\hline Bone weight $(\mathrm{kg})$ & $1.3 \pm 0.1$ & $1.3 \pm 0.1$ & $1.15 \pm 0.1$ & $1.1 \pm 0.1$ \\
\hline Bone $(\%)$ & $21.67 \pm 0.7$ & $20.63 \pm 0.4$ & $19.83 \pm 0.7$ & $18.64 \pm 0.5$ \\
\hline Fat weight $(\mathrm{kg})$ & $0.80 \pm 0.0$ & $0.70 \pm 0.0$ & $0.65 \pm 0.0$ & $0.70 \pm 0.0$ \\
\hline Fat $(\%)$ & $13.33 \pm 0.1$ & $11.11 \pm 0.1$ & $11.21 \pm 0.1$ & $11.86 \pm 0.1$ \\
\hline Meat Coefficient (lean:bone) ratio & $3.0 \pm 1.6$ & $3.31 \pm 2.8$ & $3.48 \pm 1.3$ & $3.73 \pm 2.1$ \\
\hline
\end{tabular}

The consumer demand of meat are depends on too much water holding capacity, less cooking loss and high juiciness (Manafiazar et al., 2007). Chemical composition of L.dorsi muscle of buffalo calves feed EDTA or zinc as additives was illustrated in Table (6), a higher percentage of protein (on DM\% basis) was higher for $\mathrm{T}_{3}$ and $\mathrm{T}_{1}$ groups compared with those in $\mathrm{T}_{2}$ and control ( 82.2 and $81.4 v s$. 80.5 and $80.6 \%$, respectively), however the difference in protein $\%$ among groups was insignificant. The differences in fat percentage were significant among the studies groups $\left(T_{2}\right.$ than $T_{1}, T_{3}$ and $C$ group recording (14.5vs. 13.5, 13.0 and 13.7 respectively). Ash percentage was higher in $\mathrm{C}$ group $(5.7 \%)$ which was significant $(\mathrm{P}<0.05)$, while $\mathrm{T}_{3}$ group had the lowest value $(4.8 \%)$.

Physical properties of meat including $\mathrm{pH}$ value, water holding capacity, cooking loss percentage and color intensity are presented in Table (6). There was a significant difference $(\mathrm{P}<0.05)$ among treatment groups in $\mathrm{pH}$ values which ranged from 6.28 to 6.64. Soheir et al. (1999) indicated that the $\mathrm{pH}$ values of meat from fattening buffalo calves ranged 5.46 to 5.58. On the otherhand, Kessler et al. (2003) reported 
that adding 10 ppm of zinc in Red Holstein bulls rations didn't affect significantly carcass characteristic and meat quality.

Adding EDTA or zinc had a significant effect on color intensity of meat among the experimental groups Table (6). Adding EDTA to the diet reduced $\mathrm{Zn}$ availability and liver $\mathrm{Fe}$ concentration and increased urine $\mathrm{Fe}$, caused a decline in the blood $\mathrm{Hb}$ which used as an indicator of a mild state of anaemia which may account for the reduction in DM intake so that adding EDTA effectively lightened muscle color without affecting animal performance (Serge et al., 1992). Excessive concentration of zinc in the diet may be competed with the absorption of other bivalent metals such as $\mathrm{Ca}, \mathrm{Fe}$ and $\mathrm{Cu}$ as antagonists, the concentration of these elements in blood would change as reported by (Garget al., 2008)
No significant difference was detected among the studied groups in the percentages of cooking loss and water holding capacity (Table 6).This result might be due to the little variation in moisture and connective tissue content and the positive relationship between protein percentage and WHC since proteins are the principal waterbinding constituents in meat, this was agree with the finding obtained by Soheir et al. (1999) that found that water holding capacity for buffalo calves ranged from (6.29 to $\left.8.12 \mathrm{~cm}^{2}\right)$. Other researchers report that adding zinc to a control diet increased quality grade, yield grade, marbling, and backfat of the finishing steers (Malcolm-Callis et al., 2000; Huertaet al., 2002; Spears and Kegley, 2002 and Gregory, 2006).

Table 6.Chemical composition and physical characteristics (LSM+SE) of buffalo calves fed on zinc and EDTA as food additives.

\begin{tabular}{|c|c|c|c|c|}
\hline Item & $\mathrm{C}$ & $\mathrm{T}_{1}$ & $\mathrm{~T}_{2}$ & $\mathrm{~T}_{3}$ \\
\hline \multicolumn{5}{|c|}{ Chemical composition(Fresh basis) } \\
\hline Moisture \% & $72.6 \pm 0.3$ & $72.7 \pm 0.2$ & $72.9 \pm 0.4$ & $72.7 \pm 0.5$ \\
\hline Crude protein $(\mathrm{CP}) \%$ & $22.1 \pm 0.3$ & $22.2 \pm 0.2$ & $21.8 \pm 0.2$ & $22.5 \pm 0.4$ \\
\hline Ether Extract \% & $3.8 \pm 0.2^{\mathrm{b}}$ & $3.7 \pm 0.2^{b}$ & $3.9 \pm 0.3^{\mathrm{a}}$ & $3.6 \pm 0.2^{\mathrm{b}}$ \\
\hline Ash \% & $1.6 \pm 0.2^{\mathrm{a}}$ & $1.4 \pm 0.2^{\mathrm{b}}$ & $1.4 \pm 0.2^{b}$ & $1.3 \pm 0.1^{\mathrm{b}}$ \\
\hline \multicolumn{5}{|c|}{ Chemical composition (DM basis) } \\
\hline$\overline{\mathrm{DM}} \%$ & $27.4 \pm 0.3$ & $27.3 \pm 0.2$ & $27.1 \pm 0.3$ & $27.3 \pm 0.4$ \\
\hline Crude protein $(\mathrm{CP}) \%$ & $80.6 \pm 0.2$ & $81.4 \pm 0.2$ & $80.5 \pm 0.1$ & $82.2 \pm 0.3$ \\
\hline Ether Extract \% & $13.7 \pm 0.1^{\mathrm{b}}$ & $13.5 \pm 0.1^{\mathrm{b}}$ & $14.5 \pm 0.2^{\mathrm{a}}$ & $13.04 \pm 0.1^{\mathrm{b}}$ \\
\hline Ash \% & $5.7 \pm 0.13^{\mathrm{a}}$ & $4.9 \pm 0.1^{\mathrm{b}}$ & $5.0 \pm 0.0^{\mathrm{b}}$ & $4.8 \pm 0.0^{\mathrm{b}}$ \\
\hline \multicolumn{5}{|l|}{ Phy sical characteristics } \\
\hline Cooking loss $\%$ & $40.4 \pm 0.8$ & $44.0 \pm 1.4$ & $42.6 \pm 1.3$ & $43.0 \pm 1.3$ \\
\hline Ey e muscle area $\left(\mathrm{cm}^{2}\right) *$ & $105.7 \pm 4.9^{\mathrm{b}}$ & $114.5 \pm 6.4^{\mathrm{a}}$ & $104.2 \pm 5.3^{\mathrm{b}}$ & $109.3 \pm 1.1^{\mathrm{b}}$ \\
\hline WHC $\left(\mathrm{cm}^{2}\right)^{*}$ & $6.8 \pm 0.4$ & $6.9 \pm 0.5$ & $7.5 \pm 0.2$ & $7.7 \pm 0.4$ \\
\hline color intensity $* *$ & $0.4 \pm 0.0^{\mathrm{a}}$ & $0.2 \pm 0.0^{b}$ & $0.2 \pm 0.0^{\mathrm{b}}$ & $0.2 \pm 0.0^{b}$ \\
\hline $\mathrm{pH} * * *$ & $6.6 \pm 0.0^{\mathrm{a}}$ & $6.3 \pm 0.0^{b}$ & $6.4 \pm \underline{ \pm} 0.0^{b}$ & $6.6 \pm 0.0^{\mathrm{a}}$ \\
\hline \multicolumn{5}{|c|}{$\begin{array}{l}\text { C,control group fed on a basal diet only, } \mathrm{T}_{1} \text {, fed on basal diet }+1 \mathrm{~g} \text { zinc } / \text { calf/day, } \mathrm{T}_{2} \text {, fed on basal diet with } 1 \mathrm{~g} \text { EDTA } / \mathrm{calf} / \mathrm{day} \text {, and } \mathrm{T}_{3} \text {, fed on basal die } \\
+1 \mathrm{~g} \text { zinc }+1 \mathrm{~g} \text { EDTA / calf/day. }\end{array}$} \\
\hline \multirow{2}{*}{\multicolumn{5}{|c|}{$\begin{array}{l}\text { Within the same row, means with different superscripts a,b \&c are significant at }(\mathrm{P}<0.05) \\
\text { * Eye muscle and water hold capacity was measured after chilling }\left(24 \mathrm{~h} \text {.) at } 4^{\circ} \mathrm{C} \text { by using the instrument "Digital planimeterplanix } 5,6\right.\end{array}$}} \\
\hline & & & & \\
\hline \multicolumn{5}{|c|}{$\begin{array}{l}\text { **The color intensity was determindusing the instrument "Spectronic } 21 \mathrm{D} \text { Absorance" at wave length } 542 \mathrm{~nm} \\
* * * \mathrm{pH} \text { value was determined by Microcomputer } \mathrm{pH}-\text { Vision model } 6007 \text { (Jenco) }\end{array}$} \\
\hline
\end{tabular}

Eye muscle area was higher $(\mathrm{P}<0.05)$ in $\mathrm{T} 1$ compared to $\mathrm{T} 3$, control and $\mathrm{T} 2$ groups (114.52 vs. $109.34,105.72$ and $104.24 \mathrm{~cm} 2$, respectively) (Table 6). Increasing eye muscle area in calves fed zinc may be due to higher carcass weight in this group (Galyean et al., 1995). The similar trend was reported by Spears and Kegley (2002).On the other hand, Malcolm-Callis et al. $(2000)$ found a significant decrease $(\mathrm{P}<0.05)$ in Rib eye area of beef steers fed on $\mathrm{Zn}$ supplementation compared to control group.

\section{CONCLUSION}

Thepresent results indicate that zinc supplementation make animalstended to gain weight more efficiently, achieve little increase in carcass weight and meat quality than calves supplemented with EDTA.

\section{REFERENCES}

AOAC, 1990. Official methods of analyses, 15th ed. Association of Official Analytical Chemists.Washington, DC.U.S.A

Arelovich, H.M., F.N. Owens., G.W..Horn and J.A. Vizcarra, 2000. Effects of supplemental zinc and manganese on ruminalfermentation, forage intake, and digestion by cattle fed prairie hay and urea. J. Anim. Sci.78:29722979.

AwadallaI.M., 1993. Studies of meat production from buffalo and Friesian calves fed Ammoniated. Ph. D. Thesis, Fac., of Agric. Cairo Univ. 
Bateman H.G.; C.C. Williams.; D.T. Gantt and Y.H. Chung, 2004. Effects of Zinc and Sodium Monensin on Ruminal Degradation of Lysine-HCl and Liquid 2-Hydroxy-4Methylthiobutanoic Acid.J.Dairy Sci. 87:2571-2577.

Bateman, H.G., C.C. Williams., and Y.H. Chung, 2002.Effects of supplemental zinc in high quality diets on ruminal fermentation and degradation of urea in vitro and in vivo.Prod. Anim. Sci. 18:363-367.

Duncan D.B., 1955. Multiple ranges and multiple F-tests.Biometrics, 11:1-42

El-Asheeri A.K.A., 1984.Chemical and physical characteristics of cattle meat M.Sc. Thesis, Fac. of Agric., Cairo Univ., Egypt.

El-BasionyA.Z.; H.M. El-Sayed.; E.E. Ragheb.; M.A. El-Ashry and Srour, 2001.Effect of pronifer supplementation on the performance of buffalo calves at different stages of growth and fattening. Egypt J. Nutrition of feeds Vol. 4 (Special Is sue) 641-649.

El-Kholy, A.F.; M.A.I. Salam.; M.A.M. Ibrahim and A.S. Sami, 1999. Meat quality of Egyptian buffalo and Friesian males implanted with anabolic agents. Egypt J. Anim. Prod. 36 (1): 1-8

El-SharkawyA.M.A., $\quad$ 1984.Chemical technological studies on meats. M. Sc. Thesis, Fac. Of Agric., Kafr-El-Sheikh, Tanta University.

Fadayifar A.; H. Aliarabi.; M.M. Tabatabaei.; P. Zamani.; A.A. Bahari.; M. Malecki and A.H. Dezfoulian, 2012. Improvement in lamb performance on barley based diet supplemented with zinc. Livestock Science; 144:285-289.

Galyean, M. L..;K.L. Malcolm-Callis.; S.A. Gunter and R.A. Berrie, 1995. Effects of zinc source and level and added copper lysine in the receiving diet on performance by growing and finishing steers. Prof. Anim. Sci. $11: 139-148$

Garg, A.K.; M. Vishal and R.S. Dass, 2008.Effect of organic zinc supplementation on growth, nutrient utilization and mineral profile in lambs.Animal Feed Science and Technology; 144:82-96.

Gregory L.S., (2006). Evolution of basic zinc chloride as a zinc source for cattle. Thesis submitted to the Graduation Faculty of North Carolina State University In partial fulfillment of the Requirements for the degree of Master of Science

Hakwins., 2014. Effects of subcutaneously injected $\mathrm{Ca} \mathrm{Cu}$ EDTA on concentrations of $\mathrm{Cu}$ in liver, milk production and reproductive performance in New Zealand dairy cows. New Zealand Veterinary Journal, Forthcoming articles, pp 1-6,
Hiers J. M.JR.; W.J. Miller and D.M. Blackmon, 1967. Effect of dietary cadmium and Ethylenediaminetetraacetate on dry matter digestibility and organ weights in zinc deficient and normal ruminants J. Dairy Science vol. 51, No. 2

Huerta M.; R.L. Kincaid.; J.D. Cronrath.; J. Busboom.; A.B. Johnson and C.K. Swenson, 2002. Interaction of dietary zinc and growth implants on weight gain, carcass traits and zinc in tissues on growing beef steers and heifers. Anim. Feed Sci. Technol. 95:15-32.

Hussaini S.A.; F.B. Deartherage and L.E. Kunkle, 1950.Studies on meat. II. Observation on relation of biochemical factors to change in tenderness. Feed. Techno., 4(9): 366.

JiaW.B.; Z.H. Jia.; W. Zhang.; R.L. Wang.; S.W. Zhang and X.P. Zhu, 2008. Effects of dietary zinc on performance, nutrient digestibility and plasma zinc status in Cashmere goats. Small Ruminant. Research; 80:68-72.

Kessler J.; I. Morel .; P.A. Dufey.; A. Gutzwiller ; A. Stern and H. Geyer, 2003. Effects of organic zinc sources on performance, zinc status, and carcass meat and claw quality in fattening bulls. Livest. Prod. Sci. 81:161-171.

Khalil Z.; A. Hassan.; A.B. Ali and A. Roghiyeh, 2013. Role of dietary nano-zinc oxide on growth performance and blood levels of mineral: A study on in Iranian Angora (Markhoz) goat kids. Journal of Pharmaceutical and Health Sciences. 2(1), 19-26.

Malcolm-Callis, K.J.; G.C. Duff.; S.A. Gunter.;E.B. Kegley and D.A. Vermeiree, 2000. Effects of supplemental zinc concentration and source on performance, carcass characteristics, and serum values in finishing beef steers. J. Anim. Sci. 78: 28012808

Manafiazar G.; A. Mohsenourazary.; B. Afsharihamidi and B. Mahmoodi, 2007.Comparison carcass traits of Azeri buffalo, native and crossbred (native Holstein) male calves in west AzerbaijanIran.Italian .J.animal. Sci. vol. 6, (Supply. 2), 1167-1170,

MandalG.P.; R.S. Dass.; D.P. Isore.; A.K.Garg and G.C. Ram, 2007. Effect of zinc supplementation from two sources on growth, nutrient utilization and immune response in male crossbred cattle (Bosindicus $\times$ Bostaurus) bulls. Animal Feed Science and Technology; 138:1-12.

NRC, 2000.Nutrient requirements of beef cattle.7th ed. update. National Research Council, National Academy Press, Washington DC.242 pp. 
O'Dell BL, 2000. Role of Zinc in Plasma Membrane Function. The Journal of Nutrition; 130:1432-1436.

Omar S.S., 1997. Effect of two hosing systems on some productive and reproductive traits of buffalo calves.Egypt J. Anim. Pro. 34 (2) July 75-88.

PaulkC.B.; D.D. Burnett.; M.D. Tokach.; J.L.S.S. Nelssen.; J.M. DeRouchey.; R.D. Goodband.; G.M. Hill.; K. Dritz.; D. Haydon and J.M. Gonzalez, 2015. Effect of added zinc in diets with ractopamine hydrochloride on growth performance, carcass characteristics, and ileal mucosal inflammation mRNA expression of finishing pigs. J. Anim. Sci. .93:185-196

PhiriE.C.J.H.; M. Viva.; R.T. Chibunda and L.S.B. Mellau, 2009. Effect of zinc supplementation on plasma mineral concentration in grazing goats in sub-humid climate of Tanzania.Tanzania Veterinary Journal; 26(2):92-96.

Salama Ahmed A.K.; G. Cajat.; E. Albanell.; X. Snch and R. Casals, 2003.Effects of dietary supplements of zinc-methionine on milk production, udder health and zinc metabolism in dairy goats. Journal of Dairy Science; 70:9-17.

SAS Institute Inc. 1990. SAS Procedures Guide, Version 6. SAS Institute, Inc., Cary, NC.
Serge A.; C.V. Pommier and L. Bertrand, 1992. effect of Ca-EDTA on performance, blood parameters and muscle color of grainfed Holstein veal calves. Can. J. Anim. Sci. 72: $41-50$

Soheir M. Zeidan.; A.F. El-Kholy.;M.M. Mahasen and M.A.M. Salama, 1999. Effect of rearing system on buffalo meat production of calves over fed $120 \%$ of their requirement from 6 to 12 month of age. Annals Of Agric. Sci., Moshtohor, Vol. 37(3) :1581-1593.

SolovievY.E., 1966. The meat aging.Fd. Industry Publ. Moscow.(Cited from El-Sharkaway, 1984).

Spears J.W. and E.B. Kegley, 2002. Effect of zinc source (zinc oxide vs zinc proteinate) and level on performance, carcass characteristics, and immune response of growing and finishing steers., $\mathrm{J}$ animal sci 80:2747-2752

Szakova, J.; V. Zidek and M. Miholova, 2009. Influence of elevated content of cadmium and arsenic in diet containing feeding yeast on organisms of rats. Czech J. Anim. Sci., 54: 1-9.

ZalewskiP.D.; Q.T. Ai.; G. Dion.; J. Lata.; M. Chiara and E.R. Richard, 2005. Zinc metabolism in airway epithelium and airway inflammation: basic mechanisms and clinical targets: A review. Pharmacology and Therapeutics; 105:127- 149.

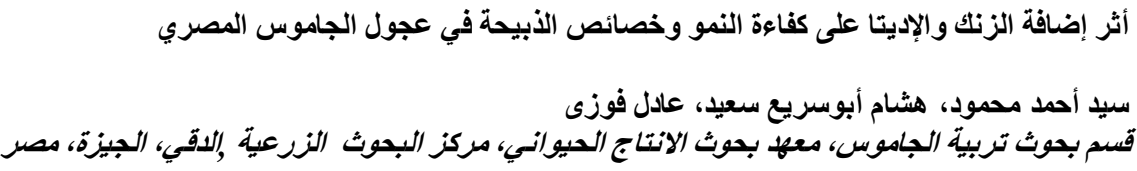

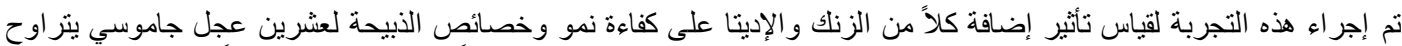

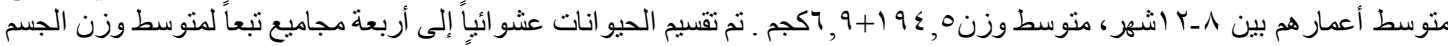

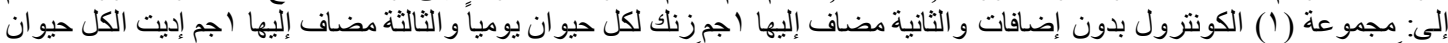

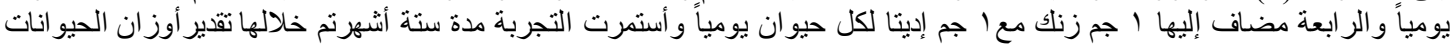

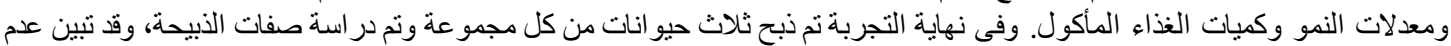

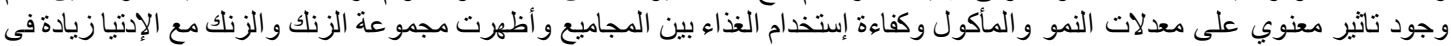

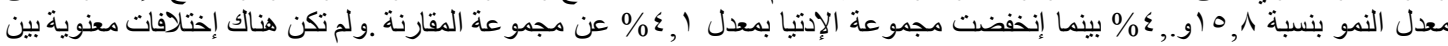

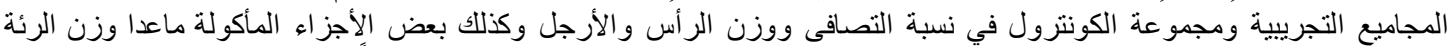

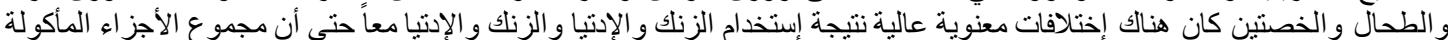

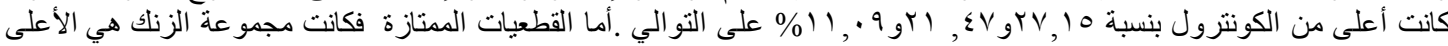

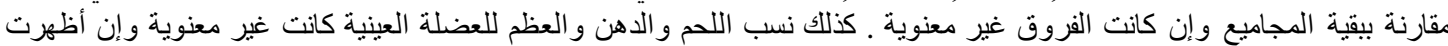

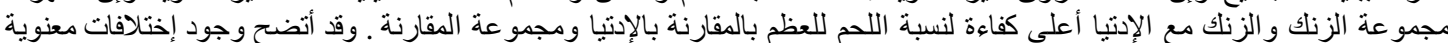

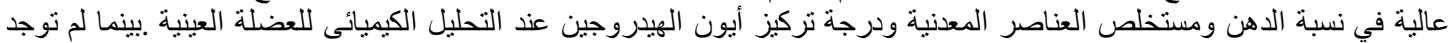

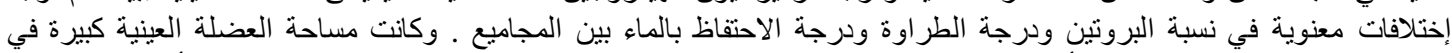

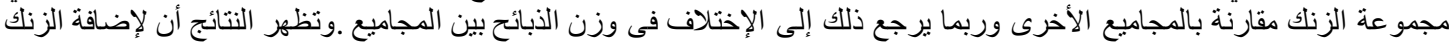
تاثير محسن على كفاءة النمو ووزن الذبع الأبيحة وخو اص اللحم بالمقارنة بإستخدام الإدنيا. 